DOI 10.22460/infinity.v6i1.239

\title{
DEVELOPMENT OF TEACHING MATERIALS ALGEBRAIC EQUATION TO IMPROVE PROBLEM SOLVING
}

\author{
Sri Adi Widodo \\ Mathematics Education, Sarjanawiyata Tamansiswa of University, Yogyakarta, Indonesia \\ sriadi@ustjogja.ac.id
}

Received: October 27, 2016 ; Accepted: January 5, 2017

\begin{abstract}
Problem-solving skills are the basic capabilities of a person in solving a problem and that involve critical thinking, logical, and systematic. To solve a problem one-way necessary measures to solve the problem. Polya is one way to solve a mathematical problem. by developing teaching materials designed using the steps in solving problems Polya expected students could improve its ability to solve problems. In this first year, the goal of this study is to investigate the process of learning the hypothetical development of teaching materials. This study is a research \& development. Procedure development research refers to research the development of Thiagarajan, Semmel \& Semmel ie 4-D. Model development in the first year is define, design, and development. The collection of data for the assessment of teaching materials algebra equations conducted by the expert by filling the validation sheet. Having examined the materials of algebraic equations in the subject of numerical methods, reviewing the curriculum that is aligned with KKNI, and formulates learning outcomes that formed the conceptual teaching material on the material algebraic equations. From the results of expert assessment team found that the average ratings of teaching materials in general algebraic equation of 4.38 with a very good category. The limited test needs to be done to see effectiveness teaching materials on problem-solving skills in students who are taking courses numerical methods.
\end{abstract}

Keywords: teaching materials, problem-solving, equation of algebra

\begin{abstract}
Abstrak
Kemampuan memecahkan masalah adalah kemampuan dasar seseorang dalam memecahkan masalah dan yang melibatkan pemikiran kritis, logis, dan sistematis. Untuk memecahkan suatu permasalahan dibutuhkan suatu cara atau langkah-langkah untuk memecahkan permasalahannya. Polya adalah salah satu cara untuk memecahkan masalah matematika. Dengan mengembangkan bahan ajar yang dirancang menggunakan langkah-langkah dalam pemecahan masalah Polya diharapkan siswa dapat meningkatkan kemampuannya untuk memecahkan masalah. Pada tahun pertama ini, tujuan dari penelitian ini adalah untuk menyelidiki proses belajar pengembangan hipotetis bahan ajar. Penelitian ini merupakan penelitian dan pengembangan. penelitian pengembangan prosedur mengacu penelitian pengembangan Thiagarajan, Semmel \& Semmel yaitu 4-D. Pengembangan model pada tahun pertama adalah mendefinisikan, desain, dan pengembangan. Pengumpulan data untuk penilaian pengajaran persamaan bahan aljabar yang dilakukan oleh ahli dengan mengisi lembar validasi. Telah memeriksa bahan persamaan aljabar dalam subjek metode numerik, meninjau kurikulum yang selaras dengan KKNI, dan merumuskan hasil belajar yang membentuk materi pengajaran konseptual pada materi aljabar persamaan. Dari hasil penilaian tim ahli menemukan bahwa peringkat rata-rata bahan ajar secara umum persamaan aljabar dari 4,38 dengan kategori sangat baik. Tes terbatas perlu dilakukan untuk melihat bahan ajar efektivitas keterampilan pemecahan masalah pada mahasiswa yang mengambil kursus metode numerik.
\end{abstract}

Kata Kunci: bahan ajar, problem-solving, persamaan aljabar 
How to Cite: Widodo, S. A. (2017). Development of Teaching Materials Algebraic Equation To Improve Problem Solving. Infinity, 6 (1), 59-68.

\section{INTRODUCTION}

Problem-solving skills are the basis of a person's ability to solve a problem involving critical thinking, logical, and systematic. Importance is given a mathematical problem can not be separated from its role in life, which is to develop one's ability to face problems. In mathematics, problem-solving skills have an important role, namely as an initial capability for students in formulating the concept and capital success for students in solving mathematical problems. In addition, students can develop an idea or ideas they have.

Troubleshooting is also becoming an important thing to be imparted to learners. One of the goals of mathematics learning is the learners are expected to foster critical thinking skills, logical, systematic, thorough, effective, and efficient in solving problems (BSNP, 2006). Whether or not the purpose of learning mathematics one of which can be seen from the success of learners in understanding mathematics and utilize this understanding to resolve the problems of mathematics and other sciences. With problem-solving, mathematics becomes not lose meaning. For a concept or principle be meaningful if it can be applied in problem solving, as expressed by Widjajanti (2009) which states that solving the problem is the process used to resolve problems.

Anisa (2014) problem-solving ability is strongly associated with the student's ability to read and understand language about the story, present in the mathematical model, plan calculation of the mathematical model, and complete the calculation of the questions that are not routine. Almost as disclosed by Windari, Dwina \& Suherman (2014) states that the study of mathematics student should be able to solve problems that include the ability to understand the problem, devised a mathematical model, solve the model, and interpret the obtained solution.

To solve the math problem required a method or systematic measures so that the process becomes the easy and effective solution. As expressed by Bransford (Purnomo \& Mawarsari, 2014), stated that the measures to solve the problem, namely (1) the identification of the problem, (2) defining the problem through the process of thinking about the problem and perform sorting the relevant information, (3) to discover its solutions through a search for an alternative, brainstorming, and the checking of different points of view, (4) implementing alternative strategies chosen, and (5) to review and evaluate the consequences of the activities undertaken, While solving problems step by Polya (1973), is understand the problem or understand the problem, make a plan, or a plan, carry out our plan or carry out the plan, and look back at the completed solution or check answers. Of these two opinions, in principle measures to solve the problem boils down to solving the problem of Polya.

In solving the problem, students sometimes do not write what is known and asked of the problems encountered. Educators so difficult to guess whether learners have understood the problems encountered or not. When educators have indicated that learners do not understand the problem, it turns out that learners are able to solve the problem correctly. But if educators have indicated that learners understand the problem, such learners have not written what is known and what is being asked. It is as expressed by Widodo (2013) states that there are some students in solving problems, which are not written what is known and what is being asked. 
The same thing also expressed by Widodo and Sujadi (2015) who found that a small percentage of learners in solving the problem, do not write what is known and what is asked, but learners are able to resolve the problems faced by correct.

In addition, the students are sometimes not able to tell what steps should be done to resolve the problem. Learners do not understand the steps necessary to plan to resolve the problem. Terms of necessary and sufficient to resolve the already can describe plans are sometimes not performed by a student. Accepted by Widodo (2013) states that learners are not able to deliver a sufficient condition and a necessary condition so that students have not been able to plan your to solve their problems.

In the phase or step to re-examine the answers, students are almost entirely not the process. Learners consider that this step makes time to solve the problem is not short (time-wasting). As expressed by Widodo (2013) learners did not do anything at this stage of checking back. In fact, if the students are able to use the stage of checking back with good, small mistakes made by learners can reduce. Different things revealed by Utomo (2012) states that at the stage of checking back in a stage that weighs most in the classification level of thinking, this is because at this stage to re-examine learners only checks the accuracy of the calculation results she had done, check systematics funds stages of its solution if it's good or not. The thought is what causes most learners do not re-examine stages in solving the problem.

Based measures such Polya, learners are only able to able to solve the problem using only the third step. For the first step, the second and fourth learners are rarely used to use in solving problems. This is why the ability to solve problems and student achievement be not optimal. Though Anisa (2014) stated that learning mathematics is successful if it produces students who have problem-solving skills, communication skills, reasoning ability, comprehension ability and the ability of other well and are able to utilize mathematical usefulness in life.

Numerical Methods is one of the subjects who learn about the techniques to solve the mathematical problems that are not able to be completed in general. One of the materials studied in numerical methods is algebraic equations. In the material algebraic equation given the problems learners including shaped polynomial equations and learners should be able to determine the roots of the polynomial equation. For example, problems in numerical methods is to determine the roots of the equation $4 x^{7}-1,25 x^{6}+120 x^{4}+15 x^{3}-120 x^{2}-x+100=0$, learners will be difficult to resolve the problem of the equation. This is what led to the achievement of students in the subject of numerical methods have not been satisfactory.

Learners still think that to solve algebra problems are not common can still use methods that are commonly used. In fact, by using numerical methods, the problems are not generally be solved. As expressed by Widodo (2014) which states that to solve algebraic equations of degree two polynomial can still use the formula abc, but to an algebraic equation with a polynomial of degree more than three will be trouble if using formula abc.

Instructional materials have a very important position in learning, ie as a representation of the explanation educator in front of the class. On the other hand, teaching materials serve as the means to achieve competence. So the preparation of teaching materials should be guided Competencies to be achieved. Teaching materials prepared without referring competence, certainly will not provide many benefits to the learners. Making teaching materials are part of the development process of innovation in education. Teaching materials used do not always have to be conventional but as educators, at least take action to repair paradigm, perspective, 
thinking, attitudes, habits, professionalism, and behavior in teaching. Thus educators deliver innovation in making teaching materials because it will have an impact on the smooth operation of student learning that is not likely to feel bored.

Development of teaching materials that originated from conventional towards innovative becomes very important because it will greatly help the learning process itself, especially teachers to assist students in learning to become interested and feel pleasant. If students have had the pleasure of learning thus studied spirit will increase. The key to the development of innovative teaching materials lies in the creativity of teachers themselves. It thus should not be an obstacle but a challenge for teachers to be able to continue to upgrade the capability to develop her potential, especially in the development of innovative teaching materials.

Along with the modern education system and the demands are growing, not infrequently schools still use conventional ways to implement the learning process. Learning in the conventional way this is usually done in solitary, which means that the learning process from the planning, implementation, to the students' learning evaluation conducted by one teacher. Planning done by teachers usually set up a book or instructional materials is nearly the same as in the previous year, even learning plan which will be used during the learning process is still the same as years previous. Whereas the preparation of plan at least have to adjust the characteristics of learners. Therefore, when teachers are still using the same plan with previous years, the teachers are indirectly learners are considered equal characteristics, whereas humans are born into the world has unique differences.

Suyono in Nugroho (2011) stated that the weakness of mathematics instruction is done by teachers at the school include the lack of ability of teachers using a variety of learning, teaching capabilities limited only to answer the questions, teachers did not want to change the learning is already considered to be true and effective, and teachers simply using conventional learning without attention to think of learners.

One of the learning tools that are used during the learning process includes instructional materials or textbooks. Instructional materials become a determining factor for learners to participate in the learning and create interest in the material to be taught. As expressed by Supriyono, Setiawan \& Trapsilasiwi (2014) states that to produce active learning, easy to understand, and fun for students requires a learning model that makes students actively participate in the learning process, the learning process which makes the students active participation during the learning process and students interested in learning that can be created by using the device.

Based on this background it is necessary to develop a learning device in this case algebraic equations teaching materials adapted to the troubleshooting steps. The hope is to develop teaching materials, academic achievement and problem-solving skills of students in the subject of numerical methods can be improved.

\section{METHOD}

The method used in this study is a model of research and development continued the experiment. The research model is the development of research methods used to produce a specific product and test the effectiveness of product (Sugiyono, 2009). Model development in this research aims to acquire problem-solving based teaching materials on the subject of 
algebraic equations. Having obtained the problem-solving based teaching materials, the next step is to conduct research experiments to see the effect of the instructional materials to the student achievement in order to obtain teaching materials based on the final solution.

RND procedure as an activity process used to develop the various aspects related to education to produce or develop. The main purpose of research and development as proposed Gay (1990) is not to test the hypothesis but rather to produce a product that can be used in education. Under these conditions, the main purpose of this research and development is to obtain teaching materials based on the material problem solving algebraic equations.

Model development of teaching materials in this study refers to the research model development of the 4-D developed by Thiagarajan, Semmel \& Semmel (1974), which define, design, development, and dissemination. According to Yusnita (2011), the advantages of model 4-D, among others: (a) more appropriate to use as the basis for developing a learning device is not to develop a learning system, (b) the description seems more complete and systematic, (c) in its development involves the assessment of experts, so that prior to being field-tested learning device has been revised based on assessment, advice, and input of experts.

Phase activities define done to establish and define the terms of development. In general, at this defining stage, activities of development needs analysis, requirements development of products that fit the needs of users as well as research and development models suited to develop products. The analysis can be done through the study of literature or preliminary research. In determining and establishing the terms of the learning device starts with (a) the analysis of the curriculum, (b) analysis of the material in the course of algebraic equations numerical methods, and (d) formulate learning objectives or learning outcomes.

At the stage of design, has prepared prototype learning device or product design (hypothetic teaching materials). At this stage to make teaching materials in accordance with the framework of the contents of the analysis results, curriculum, and materials. Prior to the design of the product proceed to the next stage, then the hypothetical teaching materials need to be validated. Validation of product design is done by a team of expert judgment as lecturers with qualifications (1) S2 mathematics education ever taught courses in numerical methods or (2) S2 applied mathematics.

At this stage of development aiming to produce learning tools which have been revised based on feedback from the experts (team of experts). The hope of teaching materials that really meet the needs of users. While the pilot phase is limited and expanded trials can not be conducted at this year due to the time of distribution and adoption of instructional materials have to adjust the distribution of curriculum by a department of mathematics education in Sarjanawiyata Tamansiswa of University.

Conceptual teaching materials have been obtained, it is necessary to assess its feasibility. To see the feasibility of teaching materials is done with content validity. The validity of the contents shows that the teaching materials are not developed at random but must be able to be justified scientifically and correctly in terms of science. Comic assessed the feasibility of teaching materials with a range of $1-5$. The indicators or aspects of an assessment (validation) comic teaching material refer to (1) structural aspects of teaching materials, (2) the material aspects of teaching materials, (3) organization, presentation and writing on teaching materials, and (4) aspects of language and legibility on teaching materials. 
Data from the analysis of the validity of teaching materials referring to the opinion of Suswina (2011) that mean $>3.20=$ highly valid, $2.40<=$ valid average $\leq 3.20,1.60<$ averages $\leq 2,40=$ quite valid , $0.80<$ mean $\leq 1.60=$ less valid, mean $\leq 0.80=$ invalid. Because the validation sheet these materials scoring range between 0-5 then the criterion of Meiriza Suswina (2011: 44-51) was adapted into a mean of $>3.75=$ excellent, $2.92<$ averages $\leq 3,75=$ Good, 1.67 $<$ averages $\leq 2,92=$ pretty good, $1.25<$ averages $\leq 1,67=$ less good, average $\leq 1,67=$ not good. As the criteria that the teaching materials created learning algebraic equations can be used for further processing (limited trial) if obtained an average score of at least 2.92.

\section{RESULTS AND DISCUSSION}

\section{Results}

The results of the validation of teaching materials are done by a team of experts to complete a validation that has been prepared. With this validation, a sheet is expected (1) to provide feasibility assessment or instructional materials algebraic equations that have been developed and (2) obtain the inputs used to revise teaching materials algebraic equations.

Table 1. Structural Aspect

\begin{tabular}{|c|c|c|}
\hline Indicator & Average & Information \\
\hline The structure of teaching materials in general interest to students & 4,50 & Very good \\
\hline See generally for learners & 4,00 & Very good \\
\hline Average & 4,25 & Very good \\
\hline
\end{tabular}

Table 2. Creative Aspects

\begin{tabular}{|c|c|c|}
\hline Indicator & Average & Information \\
\hline Material support study materials & 4.50 & Very good \\
\hline Material support learning outcomes & 5.00 & Very good \\
\hline The material is made to support understanding of the concept & 4.00 & Very good \\
\hline Truth concepts (definitions, formulas, laws, etc.) & 4.50 & Very good \\
\hline $\begin{array}{l}\text { Teaching materials support the ability of learners to problem- } \\
\text { solving }\end{array}$ & 4.50 & Very good \\
\hline Average & 4,50 & Very good \\
\hline
\end{tabular}


Table 3. Organizational, Presentation, and Writing Aspect

\begin{tabular}{lcc}
\hline \multicolumn{1}{c}{ Indicator } & Average & Information \\
\hline Proportional font to format or pictures or graphics & 4.00 & Very good \\
The material is presented in a simple and clear & 5.00 & Very good \\
Pictures on teaching materials presented with clear and attractive & 3.50 & Very good \\
\hline \multicolumn{1}{c}{ Average } & 4,17 & Very good \\
\hline
\end{tabular}

Table 4. Language and Readability aspect

\begin{tabular}{lcc}
\hline \multicolumn{1}{c}{ Indicator } & Average & Information \\
\hline Materials have been using language that is easily understood by student & 4.50 & Very good \\
$\begin{array}{l}\text { Teaching materials have been using communicative } \\
\text { Teaching materials have been using the term in accordance with the }\end{array}$ & 4.50 & Very good \\
concept of the subject & 4.50 & Very good \\
\hline average & 4.50 & Very good \\
\hline
\end{tabular}

\section{Discussion}

The first year is the development of research that aims to produce teaching materials algebraic equation as one of the subjects in the course of numerical methods. The teaching materials are instructional materials containing material algebraic equations, questions, and exercises.

Sample questions given on teaching materials is solved by using the steps in solving problems of Polya (1973), namely (1) the stage of understanding the problem, (2) phase plan to resolve the problem, (3) the stage of implementing the plan, and (4) the stage concludes the solution or the answer to solving the problem. Utomo (2012) stated that the measures implementing the plan have the greatest weight compared with other troubleshooting steps, while on stage recheck answers weigh the lowest when compared with other troubleshooting steps.

In addition the results of Widodo (2012; 2013); Widodo and Sujadi (2015) most students solve problems using only the first step that is the first step Polya that understand the problems that are implemented with length known and asked and the third step of carrying out plan implemented by step answer.

Referring to the opinion of Polya (1973) and Utomo (2012) and the findings in previous studies, the troubleshooting steps Polya adapted into three steps is to understand the problem, plan to resolve the problem, and implement plans to solving a problem. While in the fourth stage Polya which checking back answers, adapted to conclude the answer.

Having obtained the final ability possessed by the student and the material to be studied by the students, the next step is to design teaching materials conceptual. The design of teaching 
materials conceptually refers to the ability of the end possessed by students, namely (1) Students are able to apply some numerical method to solve the algebraic equation correctly, (2) Students are able to solve problems of algebraic equations using several numerical methods, and (3) the students were able to deduce which method is effectively used to solve the problem of algebraic equations, and the material to be studied by the students that real root layout, Biseksi method, method of any false, iteration method, Newton-Raphson method, and the secant method.

Teaching materials algebraic equation prepared attention steps Polya adapted: (1) understand the problem, (2) plan for a plan to resolve the problem, (3) implement a plan to resolve the problem, and (4) concludes solve the problem, it this aims to make students familiar in solving algebraic equations hopes students have the ability to solve problems and learn quite a good achievement. In addition, algebraic equations teaching materials prepared by the concept of guided problem solving, that means teaching material given sample questions along with the answers, sample questions with answers partially covered, and exercises.

The assessment of the expert team concluded that in general the teaching materials algebraic equation has been good, interesting ideas, and can be performed limited testing for effectiveness. But there are some mistakes that should be revised related to (1) Grammar equations polynomial should have been written using Microsoft equation but not yet written using Microsoft equation, (2) subtitles methods one counterfeit is recommended to be replaced with a method of positioning a fake, and (2) the calculation process in problem solving algebraic equations still wrong. From this assessment of the expert team, then it is necessary to consider these suggestions so that errors that occurred writing that occurs on conceptual teaching materials can be improved.

From Table 1 to Table 4 shows that the average score ratings were obtained from several aspects: (1) structural aspects of teaching materials gained 4.50 to excellent category, (2) a material aspect obtained 4.50 with very good categories, (3) organization, presentation and writing gained 4.17 with very good categories and (4) aspects of language and legibility obtained 4.50 with very good category. From the results of the validation of teaching materials, it can be concluded that the teaching material algebraic equation can be expressed has been very good. his result is also supported by the overall average (mean in general) in the amount of 4.38 with a very good category. To look at the effectiveness of teaching materials algebraic equations need to do limited testing prior to wider research.

Validity conducted in these studies underscore the validity of the content. The validity of the content may be declared invalid by the very good category by the validator. This is because the teaching materials developed algebraic equations in accordance with the material that should have been presented. Based on the results of the validation expert teaching materials algebraic equation of the fourth aspect of the indicator is stated that the teaching materials algebraic equations in the excellent category.

In the aspect of teaching language, the structure shows that the overall structure of the teaching materials presented very well, appealing to students. In the aspect of the material showed that the material used is very supportive of study materials and achievement of learning on the subject of numerical methods, material presented supports the understanding of the concept, the truth of the concept (definition, formula, law, and so on) is very good, teaching materials developed to support the ability of participants students in solving mathematical problems, especially algebraic equations. 
Depdiknas (2008) states that the teaching material is a set of materials arranged in a systematic, whether written or not so as to create the environment or atmosphere that allows students to learn. According to Depdiknas (2008) is a set of instructional materials arranged in a systematic matter, whether written or not so as to create the environment or atmosphere that allows students to learn. The validity so that the content or truth of the contents in science and alignment system based on values shared by a society or a nation. The contents of teaching materials algebraic equations were developed based on the concept and the prevailing theory in the field of science as well as in accordance with the development of the field and the results of empirical research conducted in the discipline.

In the aspect of the organization, presentation and writing showed that the size of the letters is in proportion with the format as well as images or graphics, the material on teaching materials are presented in a simple and clear picture on teaching materials are presented with a clear and compelling.

The high rating validator on organizational aspects, presentation and writing as well as aspects of the language and legibility due to the process of development of teaching materials simple algebraic equations attention to aspects of his performance but easy to read. As expressed by Nurseto (2011) states that in developing learning tools, developers must pay attention to the principle of "visuals", which is visible (easily seen), interesting (attractive), simple (simple), useful (it useful or beneficial), accurate (correct and accountable), legitimate (reasonable), and structured (structured / structured

\section{CONCLUSION}

The process of developing teaching materials algebraic equations only through 3 stages: (1) step of defining (define) do analyzing curriculum, materials and formulate competency and indicators of achievement of competencies, (2) the design phase (design) done by creating a prototype teaching materials algebraic equations, (3) the development stage (develop) the validation tests conducted by experts who have a background in Master in Applied Mathematics or Mathematics Education Master who taught methods of numerical mathematics materials obtained an average of 4.38 with the criteria very well.

From these results can be suggested that the result of the development of teaching materials algebraic equation can be used for experimental research or research limited.

\section{REFERENCES}

Anisa, W. N. (2014). Peningkatan Kemampuan Pemecahan Masalah Dan Komunikasi Matematik Melalui Pembelajaran Pendidikan Matematika Realistik Untuk Siswa SMP Negeri Di Kabupaten Garut. Jurnal Pendidikan dan Kebudayaan, 1(1).

BSNP. (2006). Lampiran Peraturan Menteri Pendidikan Nasional No 22 Tahun 2006. Jakarta: Depdiknas.

Depdiknas. (2008). Panduan Pengembangan Bahan Ajar. Jakarta: Direktorat Pembinaan Sekolah Menengah Atas.

Gay, L. R. (1990). Educational Evaluation And Measurement: Competencies For Analysis And Application. New York: MacMillan Pub. Comp. 
Nugroho, A. A. (2011). Pengembangan Perangkat Pembelajaran Matematika Berbasis SMART Dengan Strategi TAI Pada Materi segitiga Kelas VII. Jurnal Aksioma, 2(2).

Nurseto, T. (2011). Membuat Media Pembelajaran Yang Menarik. Jurnal Ekonomi dan Pendidikan, 8(1), 19-34.

Polya, G. (1973). How To Solve it: A New Aspect of Mathematical Method. New Jersey, USA: Princeton University Press.

Purnomo, E. A., \& Mawarsari, V. D. (2014). Peningkatan Kemampuan Pemecahan Masalah Melalui Model Pembelajaran Ideal Problem Solving Berbasis Project Based Learning. Jurnal Kajian Pendidikan Matematika, 1(1), 24-31.

Sugiyono. (2009). Metode Penelitian Pendidikan: Pendekatan Kualitatif, Kuantitatif dan $R \& D$. Bandung: Alfabeta.

Supriyono, Setiawan, T. B., \& Trapsilasiwi, D. (2014). Pengembangan Perangkat Pembelajaran Matematika Model Student Facilitator And Explaining Setting Contextual Teaching And Learning (CTL) Pada Sub Pokok Bahasan Prisma dan Limas Kelas VIII Semester Genap. Jurnal Pendidikan dan Pembelajaran PANCARAN, 3(2), 53-62.

Suswina, M. (2011). Hasil Validitas Pengembangan Bahan Ajar Bergambar Disertai Peta Konsep Untuk Pembelajaran Biologi SMA Semester 1 Kelas XI. Jurnal Ta'dib, 14(1), 44-51.

Thiagarajan, S., Semmel, D., \& Semmel, M. I. (1974). Instructional Development For Training Teachers Of Exceptional Children: A Sourcebook. Minneapolis: Central for Innovation on Teaching the Handicapped.

Utomo, D. P. (2012). Pembelajaran Lingkaran Dengan Pendekatan Pemecahan Masalah Versi Polya Pada Kelas VIII di SMP PGRI 01 Dau. Widya Warta, 36(1), 145-158.

Widjajanti, D. B. (2009). Kemampuan Pemecahan Masalah Matematis Mahasiswa Calon Guru Matematika: Apa dan Bagaimana Mengembangkannya. Seminar Nasional Matematika dan Pendidikan Matematika (pp. 402-413). Yogyakarta: FMIPA UNY.

Widodo, S. A. (2012). Proses Berpikir Mahasiswa dalam Menyelesaikan Masalah Matematika Berdasarkan Tipe Kepribadian Idealist. Yogyakarta: UST.

Widodo, S. A. (2013). Analisis Kesalahan dalam Pemecahan Masalah Divergensi Tipe Membuktikan Pada Mahasiswa Matematika. Jurnal Pendidikan dan Pengajaran (JPP), 46(2), 106-113.

Widodo, S. A. (2014). Metode Numerik. Yogyakarta: Graha Ilmu.

Widodo, S. A., \& Sujadi, A. A. (2015). Analisis Kesalahan Mahasiswa dalam Memecahkan Masalah Trigonometri. Jurnal Sosiohumaniora, 1(1), 51-63.

Windari, F., Dwina, F., \& Suherman. (2014). Meningkatkan Kemampuan Pemecahan Masalah Matematika Siswa Kelas VIII SMP N 8 Padang Tahun Pelajaran 2013/2014 dengan Menggunakan Strategi Pembelajaran Inkuiri. Jurnal Pendidikan Matematika, $3(2), 25-28$.

Yusnita, E. (2011). Pembelajaran Kontekstual Berlatar Pondok Pesantren pada Materi Garis dan Sudut di Kelas VII MTs. Seminar Nasional Penelitian, Pendidikan dan Penerapan MIPA (pp. PM 11 - PM 18). Yogyakarta: FMIPA UNY. 